\title{
Macromycetes occurring in the Violo odoratae-Ulmetum campestris in the Bielinek Reserve on the Odra river
}

\author{
ANNA BUJAKIEWICZ \\ Department of Plant Ecology and Environment Protection \\ Adam Mickiewicz University \\ Al. Niepodleglosci 14, PL-61-713 Poznań, Poland
}

$\mathrm{B}$ u j a $\mathrm{k}$ i e w i $\mathrm{c}$. A.: Macromycetes occurring in the Violo odoratae-Ulmetum campestris in the Bielinek Reserve on the Odra river. Acta Mycol. 32 (2): 189-206, 1997.

In the paper the results of a 3-year mycocoenological study carried out on 2 permanent plots marked in the Violo odoratae-Ulmetum association are presented and several ecological groups of fungi as regards substratum are discussed. Moreover, records made accidentally on macrofungi in the xerothermophilous Lithospermo-Quercetum $\mathrm{Br}_{+}-\mathrm{Bl}, 1932$ and the Linosyridi-Stipetum pulcherrimae (Libb. 1932/1933) Filipek 1974 communities are mentioned.

Key words: mycocoenology, macromycetes, Violo odoratae-Ulmetum campestris, nature reserve Bielinek.

\section{INTRODUCTION}

First mycological data from the reserve at Bielinek on the Odra river can be found in the works of S $\mathrm{marda}$ (1957) and Celi ns ki and F il i p e k (1958a, b). The data concern the sites of rare species of fungi, mainly those associated with xerothermophilous vegetation. Later data included in chorological and taxonomic works as well as in notes, namely in those of S k irg i ełło (1970, 1976, 1984), W o je wo d a (1979), Fr i e d r i c h (1991) and R u d n i c k a-J e z i e r s k a (1991) are of a similar character. So far over 40 species of fungi have been found in this area.

Until now the alluvial forest Violo odoratae-Ulmetum (Weevers 1940) H. Doing 1962 in Poland has not been a subject of extensive mycocoenological studies. First general information on the occurrence of macromycetes on patches of this forest community in the Bielinek Reserve were compiled in 
two summing up papers of the author (1989, 1992). Two-year observations in this community in the Wielkopolski National Park were also carried out by $\mathrm{S} u \mathrm{~s}$ i c k a (1994). In her work she compared her observations with earlier studies carried out in this Park (in the same reserve) in the elm alluvial forest classified at that time as the Fraxino-Ulmetum slope variant ( $\mathrm{C}$ e $\mathrm{l}$ i n s $\mathrm{k}$ i 1969) or as the Fraxino-Ulmetum variant with Ulmus (B u j a k i e w i c z 1973).

The present paper is the first comprehensive mycocoenological study on the Violo odoratae-Ulmetum alluvial forest growing in the Bielinek Reserve on the Odra river.

I would like to express my cordial thanks to all the people who helped me in my work. I am particularly grateful to the late Prof. Teofil Wojterski who inspired the research and marked of the permanent plots to be observed. I direct my thanks for valuable help in determination of some fungi to Prof. W. Wojewoda, Dr. V. Demoulin, Prof, M. Lisiewska, Dr. A. Chlebicki and the late Prof. K. Križ (Brno). I would also like to thank Dr. A. Brzeg for phytosociological consultations and $\mathrm{K}$. Szambelaniczyk, M. A, for making draught.

\section{GENERAL PHYSIOGRAPHY}

The Bielinek Reserve on the Odra river lies around $60 \mathrm{~km}$ south-west of Szczecin and is situated on the edge of the ravined valley between Bielinek and Lubiechów Dolny (Fig. 1). Steep slopes of the Odra proglacial stream valley, elevated to around $70 \mathrm{~m}$ above the valley's bottom, extend from the west to the east around $5 \mathrm{~km}$ from Bielinek. The Reserve was established in 1957 to protect forest-steppe vegetation. In 1993 it was incorporated into the Cedynia Landscape Park.

The Reserve lies between $52^{\circ} 55^{\prime}$ north latitude and $14^{\circ} 10^{\prime}$ east longitude. Its relief is diversified with numerous, relatively deep ravines (and flat-bottomed accumulation valleys) cutting the slopes of the proglacial stream valley. The forms of the contemporary ravines were shaped in the diluvial period. The exposition of the slopes ranges from southern to south-eastern and south-western, and the inclination from $10^{\circ}$ to $45^{\circ}$. Most of the ravines assume the shape of a niche and are not drained by streams ( $\mathrm{C} \mathrm{e} \mathrm{li} \mathrm{n} \mathrm{s} \mathrm{k} \mathrm{i} \mathrm{and}$ Filipe k 1958a).

The slopes of the Odra proglacial stream valley within the Reserve are built of boulder loam of ground moraine. The substratum is rich in calcium carbonates and most of the soils are of brown soil type with weakly formed humus horizon which is overgrown by xerothermophilous swards.

Soils in the ravines are formed from light loams and belong to deep humic soils. Their reaction is close to neutral. These are soils of intermediate character between brown soil and forest black earth ( $\mathrm{C} \mathrm{e} \mathrm{li} \mathrm{ns} \mathrm{k} \mathrm{and} \mathrm{F} \mathrm{ilipe} \mathrm{k}$ 1958a). 


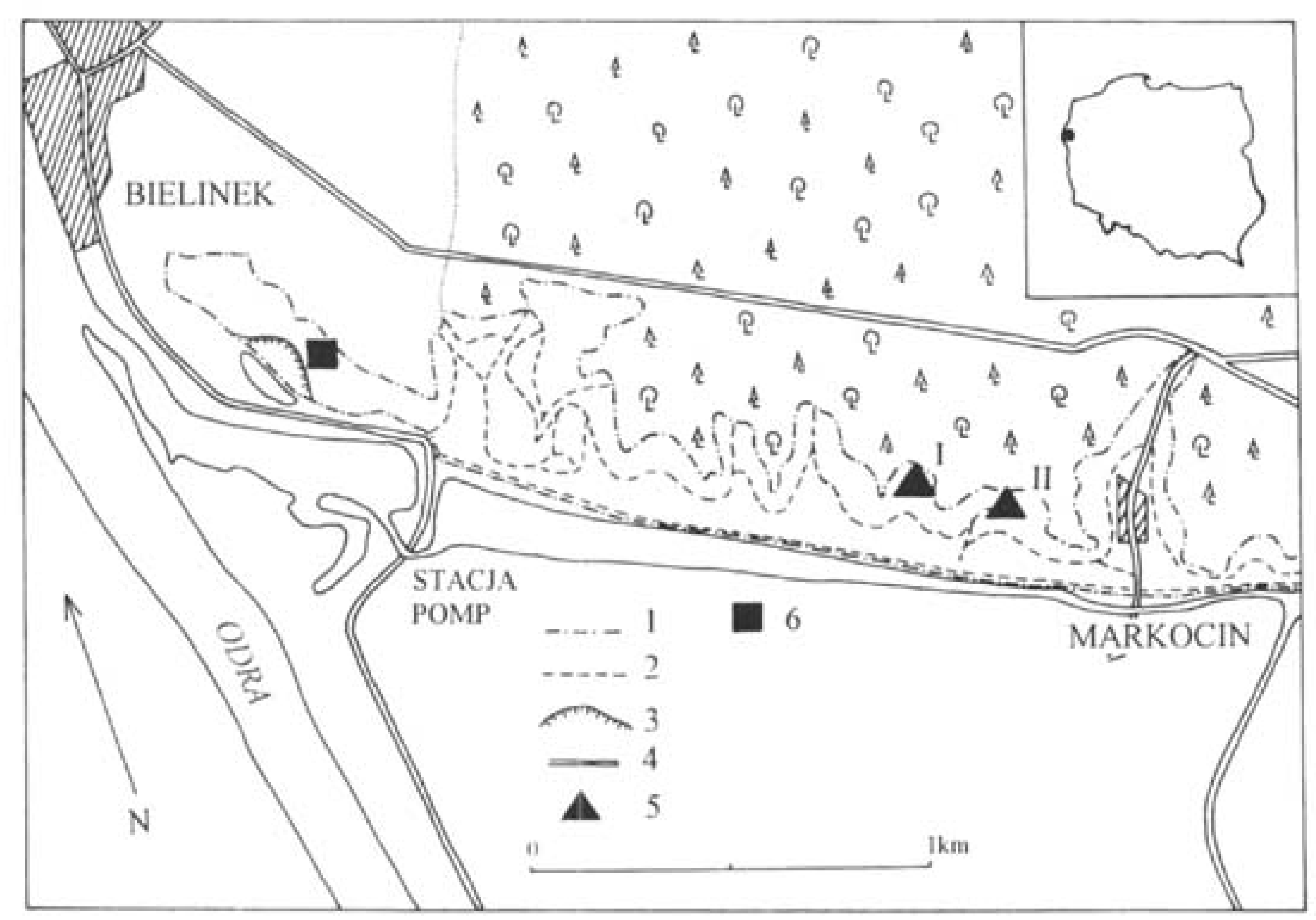

Fig. 1. Distribution of permanent plots in the Bielinek Reserve: 1 - boundaries of the Reserve; 2 - paths, 3 - claypit, 4 - roads, 5 - permanent plots, 6 - locality of Geastrum melanocephalum (Crern.) Stanek

According to the climatic regionalisation of Poland (W o ss 1996), the discussed area lies within the boundaries of West Pomerania. It is a region with relatively the smallest number of days with ground-frost, moderately cold with precipitation (10 days in a year) and with the smallest number of days with moderately frosty weather with precipitation ( 7 days in a year). The Reserve is located on the north-west edge of the Wielkopolska Lowland where the total annual precipitation in the years 1950-1980 amounted to less than $550 \mathrm{~mm}$. According to $\mathrm{Celi} \mathrm{n} \mathrm{s} \mathrm{k} \mathrm{i} \mathrm{and} \mathrm{F} \mathrm{il} \mathrm{i} \mathrm{pe} \mathrm{k} \mathrm{(1958a)} \mathrm{total} \mathrm{annual} \mathrm{precipita-}$ tion in the reserve equals $480 \mathrm{~mm}$. The annual mean air temperature in the vicinity of the study area equals $8.4^{\circ} \mathrm{C}$ (W o s 1994).

Microclimatic conditions on open slopes and in shaded ravines are totally different and they determine the occurrence of two different plant formations, swards and forests. Xerothermophilous swards concentrate on strongly insolated open slopes with considerable oscillations of temperature within a day and day and night. In the shady ravines the amount of light is limited and the temperatures are more stable. Relative moisture on the slopes on sunny days amounts to $20-30 \%$, while in the ravines it rarely falls below $60 \%$ ( $\mathrm{C} \mathrm{eli} \mathrm{ns} \mathrm{ki}$ and $\mathrm{Filipe} \mathrm{k} \mathrm{1958a).}$ 
According to Poland's geobotanic division (M a t u s z k i e w i c z 1993) the area studied lies within the Pomerania Divide in the Szczecin Province and the Cedynia District. The province is distinguished due to the occurrence in some sites of thermophilous oak forests and of steppe sward communities.

The vegetation landscape of the reserve in Bielinek on the Odra river is dominated by xerothermophilous swards which form here the largest concentration in Pomerania (C e l i n s k i and F i l i p e k 1958a; F i l i p e k 1974). They form communities close to the Linosyridi-Stipetum pulcherrimae (Libb. 1932/1933) Filipek 1974, which, at present, undergo a constant intensive process of overgrowing with Robinia pseudacacia, Prumus spinosa and Acer campestre.

Large areas, particularly on southern and eastern slopes, are occupied by phytocoenoses of xerothermophilous forest-scrub community Lithospermo-Quercetum Br. Bl. 1932 (=Lithospermo-Quercetum subboreale Mat. 1955), On the slopes and on the bottom of larger ravines (Markocin) the beech-ash tree stands occur.

The elm alluvial forests with Viola odorata are a peculiar forest community in the Reserve. In Poland they were described for the first time in this area by Celinski and Filipek under the name Fraxino-Ulmetum (Tx. ap. Lohm.) Oberd. 1953 violetosum odoratae. These slope alluvial forests are the subject of the mycocoenological investigation in the present paper.

\section{METHODS OF RESEARCH}

In the patches of the alluvial elm forest overgrown with Viola odorata two permanent plots of 400 sq.m each were established (Fig.1). On each plot during three years of study (1974-1976) 18 mycocoenological surveys were carried out from April to November. In each observation period the presence and the number of epigeous sporocarps in the quadrat as well as the colonised substratum were noted.

The composition and diversity of vascular associations were determined with the Brown-Blanquet method (Table 1).

Three main ecological groups of macrofungi were distinguished with regard to their substratum (Table 2). The first number in the column represents the number of records and the letter in power exponent denotes the estimate abundance (acc. to J a h n et. al. 1976). Records made outside the plots, but within the alluvial elm forest are marked with parentheses.

Sporadic collections of macrofungi were also made in the xerothermophilous swards, Linosyridi-Stipetum pulcherrimae and in the scrub-forest, Lithospermo-Quercetum.

The nomenclature of macrofungi agrees, in most respects, with those used by the following authors: $\mathrm{D}$ e $\mathrm{n} \mathrm{n}$ is (1978), $\mathrm{H}$ a $\mathrm{n}$ se $\mathrm{n}$ and $\mathrm{K} \mathrm{n}$ u ds e $\mathrm{n}$ 
(1992), J ü $1 \mathrm{i}$ ch (1984), M o ser (1983) and W a t $1 \mathrm{ing}$ (1984). The collection of macrofungi was deposited in the Herbarium of the Department of Plant Ecology and Environment Protection at Adam Mickiewicz University in Poznań (POZM).

\section{DESCRIPTION OF THE STUDIED FOREST}

The Violo odoratae-Ulmetum association is the eutrophic alluvial scrubforest with sub-Atlantic distribution range, growing on steep slopes of proglacial stream valleys and cliffs. P i o t $\mathrm{r}$ o w s k a (1985) noted this association in the Wolin Island and B r z e g (1989) in the Prosna and Warta Interfluve. In Poland phytocoenoses of this association seem to be recognised with an increasing frequency. They can occur in a natural form on steep scarps of river valleys, and these are the conditions they probably find in the ravines of the Bielinek Reserve on the Odra river. This type of alluvial forest may also form patches of anthropogenic character transformed from phytocoenoses of the Ficario-Ulmetum campestris alluvial elm forest or from the eutrophised oak-hornbeam forest habitats.

In the Bielinek Reserve the alluvial forest grows in ravines above the scarps of the Odra proglacial stream valley located in a considerable distance from the present river bed. It occurs on the slopes and on the bottom of rather deeply incised ravines (300-500 metres long) on fertile, highly humic soils.

Violo odoratae-Ulmetum is a community of nitrophilous-thermophilous character. It belongs to the Alno-Padion alliance. In the tree-stand of the studied alluvial forest Ulmus campestris, Acer campestre, Quercus robur and Fraxinus excelsior prevail (Table 1).

On the permanent plot in the Elm Ravine compact scrubs of Ulmus campestris var. suberosa occurred. On the bottom of the forest there were many elm logs, fallen as a result of the Dutch elm disease.

The observation plot in the Wild Service Ravine was characterised by a high share of the oak in the tree-stand. Outside this plot only rare, individual service trees (Sorbus torminalis) and pine trees (Pinus sylvestris) grew. Only a small quantity of decaying wood was found in this plot.

In the studied alluvial forest there is a large admixture of the representatives of the Rhamno-Prunetea class (Table 1). The herb layer is highly uniform and relatively loose, especially in summer and in autumn. From among the species characteristic of and distinctive for the alluvial forest association nitrophilous species e.g. Viola odorata, Veronica hederifolia and Galium aparine are the most numerous ones. 
Ta ble

Violo odoratae-U/metum campesiris in the Biclinck Reserve on the Odra river

\begin{tabular}{|c|c|c|c|}
\hline Successive number & & 1 & 2 \\
\hline Number of plot & & 1 & II \\
\hline Date & & $3,06.1976$ & 3.06 .1976 \\
\hline Exposition & & W & W \\
\hline Inclination & & 20 & 10 \\
\hline \multicolumn{4}{|l|}{ Density } \\
\hline & $a_{1}$ & 40 & 50 \\
\hline & $a_{2}$ & 60 & 40 \\
\hline & $b^{2}$ & 100 & 50 \\
\hline \multicolumn{4}{|l|}{ Cover } \\
\hline & $\mathrm{c}$ & 100 & 80 \\
\hline & d & 20 & - \\
\hline Area of record in sq.m. & & 400 & 400 \\
\hline Height of trees in $\mathrm{m}$ & & 25 & 25 \\
\hline Average diameter in $\mathrm{cm}$ & & 53 & 60 \\
\hline Number of species & & 22 & 30 \\
\hline \multicolumn{4}{|c|}{ Ch. D. Violo odoratae-Ulmetum ass. } \\
\hline Viola odorata & $\mathrm{c}$ & 2,3 & 2,2 \\
\hline Veronica hederifolia & & 2,2 & 2,2 \\
\hline Galium aparine & & 1,1 & 2,2 \\
\hline Primula officinalis & & + & + \\
\hline Adoxa moschatellina & & & 1,2 \\
\hline Allim ofr. schoenoprassum & & & 1,2 \\
\hline Alliaria officinalis & & $=$ & + \\
\hline \multicolumn{4}{|c|}{ Ch. Alno-Padion, Fagetalia, Querco-Fagetea } \\
\hline Ulmus campestris & $a_{1}$ & 2,2 & . \\
\hline Ulmus campestris & $a_{2}$ & 4,4 & . \\
\hline Ulmus campestris & $b$ & 4,4 & . \\
\hline Ulmus campestris & $\mathrm{c}$ & 2,3 & . \\
\hline Fraxinus excelsior & $a_{i}$ & + & 3,3 \\
\hline Fraxinus excelsior & $a_{2}$ &. & 1,1 \\
\hline Fraxinus excelsior & $b$ & 1,1 & + \\
\hline Fraxinus excelsior & $\mathrm{c}$ & + & 1,1 \\
\hline Acer plaranoides & b & $=$ & + \\
\hline Acer platanoides & $\mathrm{e}$ & + & . \\
\hline Acer pseudoplatanus & c & $=$ & + \\
\hline Acer campestre & $\mathrm{b}$ & 1,1 & 4,4 \\
\hline Acer campestre & e & 1,1 & + \\
\hline Quercus robur & a & $=$ & 3,3 \\
\hline Quercus robur & $\mathrm{c}$ & 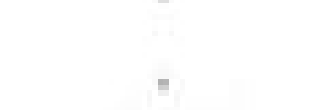 & + \\
\hline 'Ficaria verna & & 5,5 & 4,4 \\
\hline Brachypodium silvaticum & & 2,2 & 1,2 \\
\hline Agropyron canium & & 1.2 & + \\
\hline Circaea lutetiana & & + & 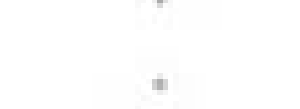 \\
\hline Viola mirabilis & & $=$ & 1,1 \\
\hline
\end{tabular}


Poa nemoralis

Dryopteris filix-mas

Fagus silvatica

Sanicula europaea

Ch. Rhamno-Prinetea

Crataegus monogyna

Crataegus monogyna

Crataegus oxyacantha

Evonymus europaea

Sambucus nigra

Rhammus catharfica

Towarzyszace (Accompanying)

Lamium maculatum

Geum urbanum

Urtica dioica

Moehringia trinervia

Arctium sp.

Aegopodium podagraria

Polygonum convolvulus

Eurhynchim hians

Fissidens taxifolius

\begin{tabular}{|c|c|c|}
\hline &. & 1,2 \\
\hline & . & + \\
\hline &. & + \\
\hline & . & + \\
\hline $\mathrm{a}_{2}$ & . & 1,1 \\
\hline $\mathrm{c}$ & $=$ & + \\
\hline b & . & + \\
\hline c & + & + \\
\hline c & 1,1 &. \\
\hline c & & + \\
\hline c & 2,3 & 1,1 \\
\hline & 2,2 & + \\
\hline & 1,2 & 1,1 \\
\hline & + & + \\
\hline & + & + \\
\hline & $\therefore$ & 4,4 \\
\hline & $\because$ & 1,1 \\
\hline d & 2,2 & 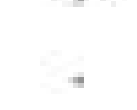 \\
\hline & 1,2 & \\
\hline
\end{tabular}

Explanation:

1 - data from April 1976

I - permanent plot marked in so called Elm Ravine (Ulmus campestris)

II - permanent plot marked in so called Wild Service Ravine (Sorbus torminalis)

\section{MACROFUNGI OF THE VIOLO ODORATAE-ULMETUM ASSOCIATION AND THE ADJACENT VEGETATION}

The list of macromycete species recorded in the phytocoenoses of the studied alluvial forest is not long. Similarly to the riverside alluvial forest of the Ficario-Ulmetum campestris type the group of epigeous fungi is the least numerous (Table 2). It is very likely that in the case of the studied phytocoenoses the low numbers of macromycetes noted result also from the specific character of the habitats occupied by the slope alluvial forest. These habitats are small forest islands surrounded with the xerothermophilous scrub-forest and sward vegetation. Dry vegetation periods in the years of observations (1974-1976) were an additional inhibiting factor.

Majority of the macromycete species occurring in the Violo odoratae-Ulmetum alluvial forest are fungi commonly noted in the broad-leaved forests of Querco-Fagetea type and the Alno-Padion alliance. Among the species characteristic of this alliance ( $\mathrm{B} \mathrm{ujak} \mathrm{i} \mathrm{w} \mathrm{icz} \mathrm{1989)} \mathrm{in} \mathrm{the} \mathrm{studied}$ phytocoenoses from litter saprotrophs group Marasmius torquescens, Mycena speirea and Hymenoscyphus albidus, and from the wood-dwelling 
Table 2

Macromycetes occurring in phytocoenoses of the Violo odoratae-Ulmetum campestris in the Bielinek Reserve on the Odra river

\begin{tabular}{|c|c|c|}
\hline $\begin{array}{l}\text { Number of plot } \\
\text { Area of plot in sq.m. } \\
\text { Number of observations } \\
\text { Number of taxa }\end{array}$ & $\begin{array}{c}1 \\
400 \\
18 \\
71\end{array}$ & $\begin{array}{c}11 \\
400 \\
18 \\
72\end{array}$ \\
\hline 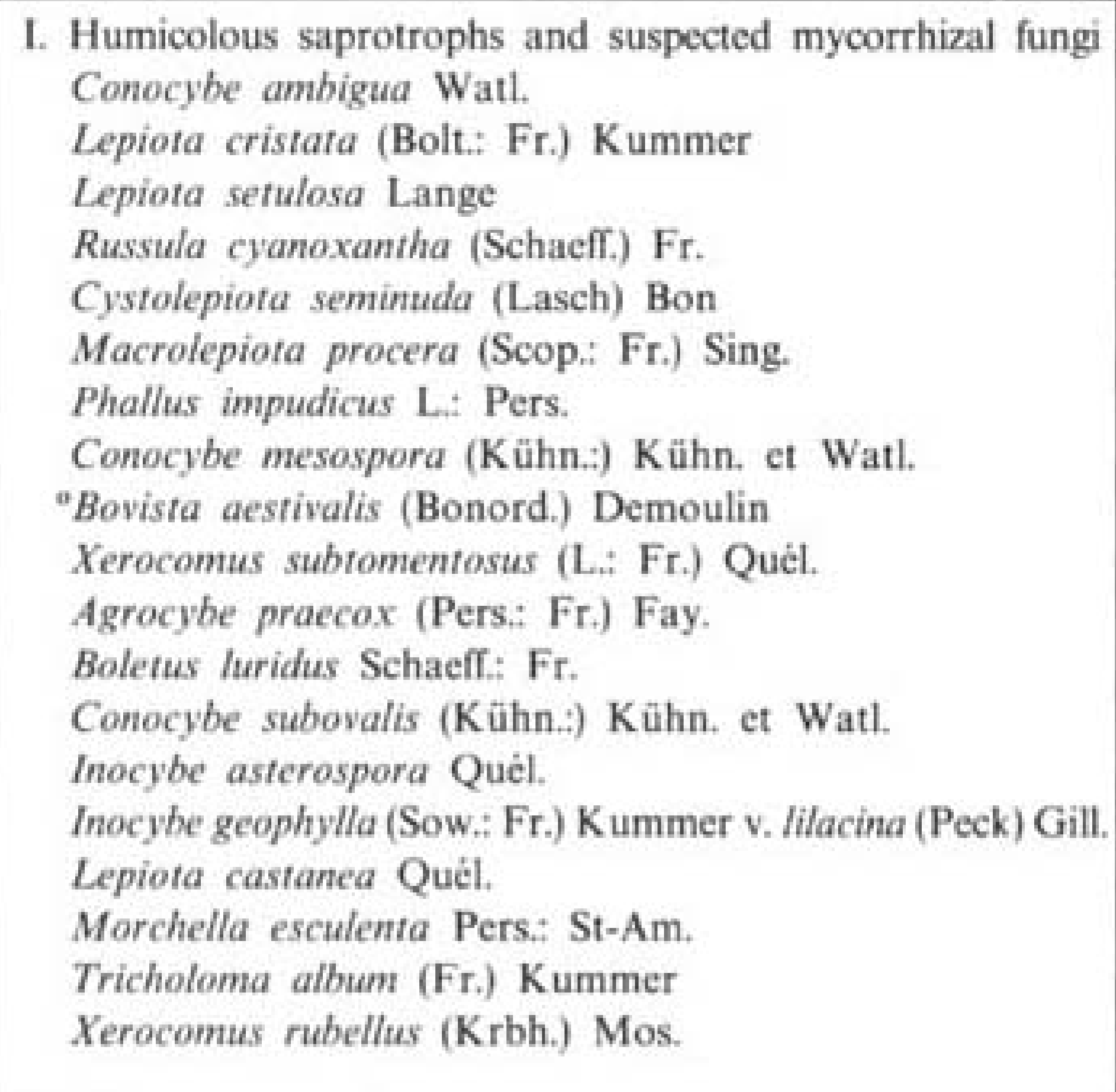 & $\begin{array}{c}1^{r} \\
\left(1^{r}\right) \\
1^{r} \\
1^{r} \\
3^{\prime} \\
3^{r} \\
2^{\prime}\end{array}$ & $\begin{array}{c}1^{r} \\
2^{r} \\
1^{r} \\
4^{r} \\
2^{r} \\
2^{r} \\
1^{r} \\
1^{r} \\
1^{r} \\
1^{r} \\
1^{r} \\
1^{r} \\
1^{r} \\
1^{r} \\
1^{r}\end{array}$ \\
\hline $\begin{array}{l}\text { 11. Litter saprotrophs } \\
\text { "Marasmius torquescens Quél. } \\
\text { Mycena speirea (Fr.: Fr.) Gill. } \\
\text { Marasmius rotula (Scop.: Fr.) Fr. } \\
\text { Coprinus impatiens (Fr.) Quél. } \\
\text { Collybia confluens (Pers.) Kummer. } \\
\text { Mycena cfr. flavoalba (Fr.) Quél. } \\
\text { Psathyrella candolleana (Fr.: Fr.) Maire } \\
\text { Marasmius scorodonius (Fr.: Fr.) Fr. } \\
\text { Mycena amicta (Fr.) Quél. } \\
\text { Mycena galopus (Pers.: Fr.) Kummer v. nigra (FL. Dan.) } \\
\text { Mycena tenella (Fr.) Quél. } \\
\text { Mycena zephirus (Fr.: Fr.) Kummer } \\
\text { Pluteus phlebophorus (Ditm.: Fr.) Kummer } \\
\text { Psathyrella subnuda (Karst.) A. H. Smith } \\
\text { Psathyrella cf. tephrophylla (Romagn.) Bon } \\
\text { Mycena galopus (Pers.: Fr.) Kummer } \\
\text { Mycena vitilis (Fr.) Quél. } \\
\text { Mycena filopes (Bull.: Fr.) Kummer } \\
\text { Tubaria furfuracea (Pers.. Fr.) Gill. } \\
\text { Clitocybe gibba (Pers.) Kummer }\end{array}$ & $\begin{array}{l}7^{n} \\
5^{r} \\
4^{r} \\
2^{r} \\
1^{r} \\
1^{r} \\
1^{n} \\
1^{r} \\
1^{r} \\
1^{r} \\
1^{r} \\
1^{r} \\
1^{r} \\
1^{r} \\
1^{r} \\
7^{n} \\
5^{n} \\
3^{r} \\
3^{r} \\
2^{r}\end{array}$ & $\begin{array}{l}2^{r} \\
6^{\mathrm{n}} \\
2^{\mathrm{n}} \\
2^{\mathrm{r}} \\
1^{\mathrm{n}}\end{array}$ \\
\hline
\end{tabular}


Collybia dryophila (Bull.) Quél.

Lepista nuda (Bull.: Fr.) Cooke

Collybia butyracea (Bull.) Quél.

Mycena pura (Pers.: Fr.) Kummer

Hymenoscyphus fructigenus (Bull.: Fr.) S. F. Gray

Collybia peronata (Bolt.) Sing.

Cyathus striatus (Huds.) Willd.

"Marasmíus bulliardii Quél.

Lepisra nebularis (Batsch: Fr.) Harmaja

Hydropus subalpinus (Hochn.) Sing.

Hymenoscyphus albidus (Roberge) Phill.

Hymenoscyphus caudatus (Karst.) Dennis

Mycena polyadelpha (Lasch) Kühn.

Clitocybe langet Sing.: Hora

Clitocybe fragrans (With:: $\mathrm{Fr}_{-}$) Kummer

Collybia asema ( $\mathrm{Fr}_{r}$ ) Kummer

Coprinus domesticus (Bolt.: Fr.) S. F. Gray

Coprinus plicatilis (Curt.) Fr.

Crocicreas cyathoidewm (Bull.) Carpenter

Psathyrella trepida (Fr.) Gill.

Strobilurus tenacellus (Pers.) Sing.

III. Lignicolous saprotrophs

Hirneola auricula-judae (Bull.: St-Am.) Berk.

Pluteus atricapillus (Secr.) Sing.

Coprinus silvaticus Peck.

Exidia plana (Wigg: Schleich.) Donk

Flammulina velutipes (Curt.) Sing.

"Coniophora puteana (Schum.: Fr.) P. Karst.

- Dacrymyces capitatus Schw.

Polyporus arcularius (Batsch): $\mathrm{Fr}_{\mathrm{r}}$.

-Radulomyces con/luens (Fr.) Christ.

- Dacrymyces sillatus Ness.: Fr.

Polyporus badius (Pers.) Schw.

* Cylindrobasidium evolvens (Fr.) Jül.

Galerina unicolor ( $\mathrm{Fr}_{\mathrm{r}}$ ) Sing.

- Byssomerulius corium (Fr.) Parm.

Clinocybe lignatilis (Pers: $\mathrm{Fr}_{\text {r. }}$ ) Karst.

Encoelia furfuracea (Roth.) P. Karst.

Ganoderma applanatum (Pers.) Pat.

Hymenoscyphus calyculus (Sow.: Fr.) Phill.

Mycena acicula (Schaeff.: Fr.) Kummer

Mycena debilis (Fr.) Quél.

Mycena olida Bres.

Oudemansiella radicata (Relh.) Sing.

* Phellinus ferruginosus (Schrad.: Fr.) Pat.

Pluteus semibulbosus (Lasch ap, Fr.) Gill.

Psathyrella of, storea (Fr.) s. K. et R.

Simocybe reducta $\left(\mathrm{Fr}_{\mathrm{r}}\right) \mathrm{Karst}$.

Stereum rugosum (Pers.) Fr. 
cont. Table 2

\begin{tabular}{|c|c|c|}
\hline $\begin{array}{l}\text { Number of plot } \\
\text { Area of plot in sq.m. } \\
\text { Number of observations } \\
\text { Number of taxa }\end{array}$ & $\begin{array}{c}1 \\
400 \\
18 \\
71\end{array}$ & $\begin{array}{l}\text { II } \\
400 \\
18 \\
72\end{array}$ \\
\hline 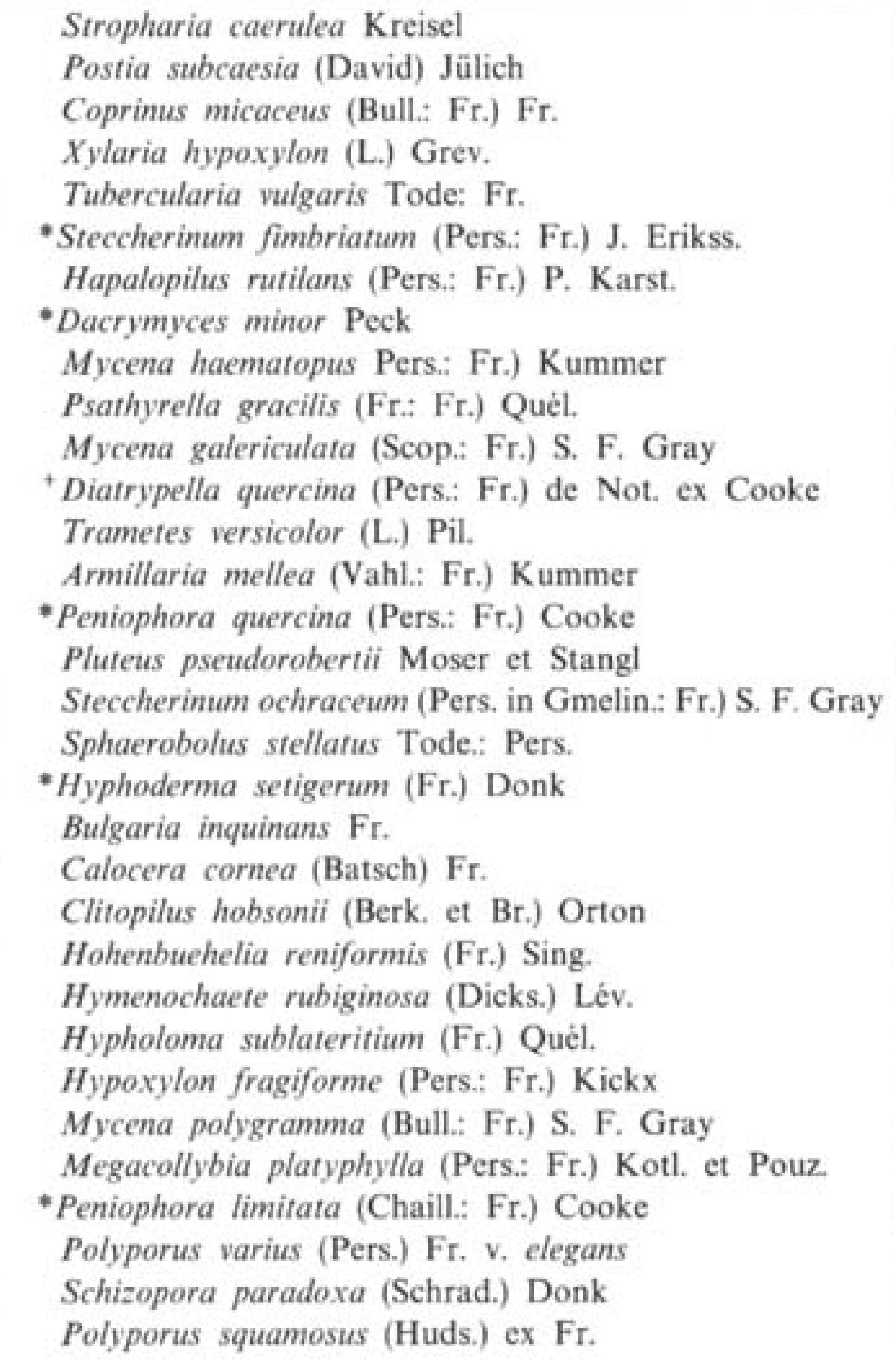 & $\begin{array}{l}1^{r} \\
4^{n} \\
5^{a} \\
4^{n} \\
2^{n} \\
2^{r} \\
2^{r} \\
1^{r} \\
1^{r} \\
1^{r} \\
1^{r}\end{array}$ & $\begin{array}{c}1^{r} \\
2^{n} \\
2^{n} \\
1^{n} \\
1^{n} \\
1^{r} \\
1^{r} \\
1^{r} \\
\left(1^{n}\right) \\
3^{r} \\
5^{n} \\
4^{n} \\
4^{n} \\
2^{r} \\
2^{r} \\
2^{r} \\
1^{n} \\
1^{r} \\
1^{r} \\
1^{r} \\
\left.1^{r}\right) \\
1^{r} \\
1^{r} \\
1^{r} \\
1^{r} \\
1^{r} \\
1^{r} \\
1^{r} \\
1^{r} \\
1^{n}\end{array}$ \\
\hline $\begin{array}{l}\text { IV. Fungi on living trees } \\
\text { Mycena pseudocorticola Kühn. } \\
\text { Psathyrella spadicea (Schaeff.) Sing. }\end{array}$ & $\begin{array}{l}1^{\prime} \\
1^{r}\end{array}$ & \\
\hline
\end{tabular}

Explanations:

I. II - permanent plots (compare Tab. I)

a.n.r. - degree of abundance (Jahn et al, 1967)

- - abundant

" - numerous

- det. W. Wojewodi

- det. V. Demoulin

+ - det. A. Chlebicki

i - rare

- rev. M. Lisiewska 
fungi Polyportus squamosus and Mycena pseudocorticola, were recorded. A r nolds et al. (1995) associate with Alno-Padion also Steccherinum fimbriatum.

The composition of macromycetes in the studied alluvial forest is close to the Ficario-Ulmetum campestris alluvial forest, which would confirm both Celiński's and Filipek's (1958a) as well as Piotrowska's (1983) opinion on the floristic and ecological affinity of these two types of alluvial forests.

The group of humicolous saprotrophs and ectomycorrhizal fungi comprises 19 species and has $60 \%$ of taxa in common with the Ficario-Ulmetum campestris alluvial forest. From the species characteristic of the Ficario-Ulmetum campestris (B u j a k i e w i c z 1989) the following ones occur in the studied alluvial forest: Morchella esculenta, Cystolepiota seminuda and Xerocomus rubellus.

The main components of the tree-stand: the elm, ash tree and maple tree do not form ectomycorrhizae but a large number of ectomycorhizal fungi is usually developed by the oak (W a $\mathrm{t} \operatorname{lin} \mathrm{g} \mathrm{1995)}$ ). However, in the studied alluvial forest there is a small quantity of fungi associated with that tree (Inocybe asterospora, Tricholoma album). They occur in greater numbers in Lithospermo-Quercetum forest, e.g. Amanita phalloides, Boletus impolitus, B. luridus, Lactarius quietus.

A group distinguishing the studied phytocoenoses of the Violo odoratae-Ulmetum is the group of humiculous and litter saprotrophs associated with light forests and grassy forest edges, e.g. Macrolepiota procera and related to base soils and to the presence of calcium carbonate, e.g. Lepiota castanea ( $\mathrm{Enderle}$ and K r i e g e lste i n e r 1989) as well as those growing on grassy swards, such as Bovista aestivalis noted also on Tortulo-Phleetum swards and Marasmius scorodonius (A $\mathrm{r} \mathrm{n}$ ol $\mathrm{d} s$ et al. 1995).

The nitrophilous character of the studied alluvial slope forest is confirmed by the occurrence of Lepiota cristata, which grows also in synanthropic habitats (K r e is e 1 1987), as well as Conocybe ambigua, C. mesospora and C. subovalis (W a $\mathrm{t} 1 \mathrm{i} \mathrm{ng} \mathrm{1982)}$ and Coprinus micaceus.

Among litter saprotrophs (41 species) constant elements were $M a$ rasmius torquescens and Clitocybe gibba and Lepiota nebularis forming "fairy-rings".

Outside of the study area Hydropus subalpinus occurred. It is a species rarely found in Poland ( $\mathrm{G} u \mathrm{~m}$ i n s k a 1994), associated with beech litter and with soils rich in calcium carbonate ( $\mathrm{K}$ r e is e 1 1987).

In the group of lignicolous saprotrophs (59 species) a constant and abundant occurrence of Hirneola auricula-judae attracts our attention (Fig. 2). In the studied Reserve this fungus, which is associated mainly with Sambucus nigra and usually accompanies man, occurs exclusively on elms. According to 
W o je w o d a's (1977) opinion it is not found in natural plant communities. The constant presence of this species in the studied alluvial forest might confirm the further presumption of this author that in the past the fungus probably occurred as a natural element in alluvial forests. In certain regions of Poland Hirneola auricula-judae is a common species and reaches in our country its north-eastern boundary of distribution (W o j e w o d a 1979).

Also Dacrymyces capitatus deserves our special attention. It shows proper vitality, forming numerous fruit-bodies on decorticated elm logs covered with mosses (Hypnum cupressiforme v, uncinatulum). They were noted on 9. July 1974 and 18. October 1976. In Poland the fungus is regarded as endangered. F r i e d r i h (1991) recorded it in the Bielinek Reserve protection zone. According to R e i d (1974) it is a cosmopolitan fungus, prefering the wood of broad-leaved trees.

In the alluvial forest phytocoenoses in which oak occurred Diatrypella quercina, Peniophora quercina and Hymenochaete rubiginosa were noted closely related to this tree (W a $t / \mathrm{in} g$ 1974). A relatively low occurrence of rarely found in Poland Peniophora limitata accompanying elm was recorded (W o je wo d a 1974). It is an endangered species (W o je w o d a and Ła w r y n o w i c z 1992).

The occurrence of fruit bodies of Mycena pseudocorticola on the bark of live elms seems to be a distinguishing characteristics of the Violo odoratae-Ulmetum alluvial forest. This relationship was observed in the Wielkopolski National Park (B u j a k i e w i c z 1973).

The comparison of the composition of macromycetes occurring in the Violo odoratae-Ulmetum alluvial forest in Bielinek with the data from Wielkopolski National Park (B u j a k i e w i c z 1973; S u s i c k a 1994) indicates a group of species which at the present stage of research can be treated as species distinctive for this association. These are Cystolepiota seminuda, Lepiota cristata, Marasmius torquescens, Mycena speirea and Mycena pseudocorticola.

In the Bielinek Reserve in the Violo odoratae-Ulmetum association the occurrence of Scutellinia cf. scutellata (L.) Lambotte and on silt and clayey soil, Greletia planchonis Dun. ex Boud. (=Smardaea p. Dun. ex Boudier, Korf et W.-y. Zhuang) were noted (leg. et det. H. Dissing, Copenhagen P.81.50 and P.81.49, Dissing personal communication). Greletia planchonis is an epigeous saprotroph occurring for instance on the Canary Islands (K o r f et al. 1991).

On the slopes of the forested Markocin ravine, under beech (Fagus sylvatica) and ash (Fraxinus excelsior) the following macrofungi were noted: Cyathus striatus (Huds.) Willd, Exidia truncata Fr. (det. W. Wojewoda), Marasmius torquescens Quél., $M$. cf. wynnei Bk. et Br. (det. M. Lisiewska), 


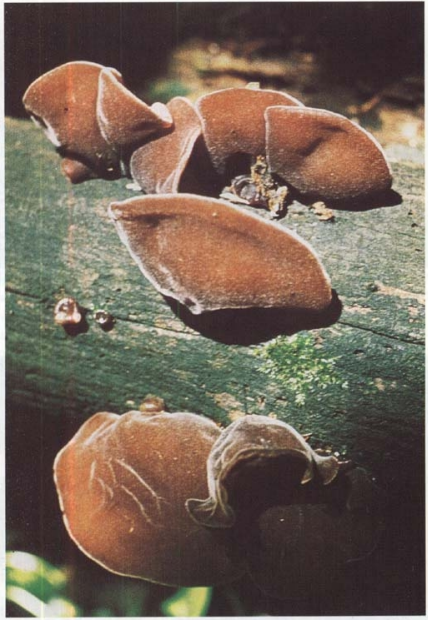

Fig. 2. Hirneola auricula-judae on dead decorticated elm (Ulmus campestris) in the Violo odoratre-Ulmetum association in the Bielinek Reserve on the Odra tiver (Phot. A. Bujakiewiez) 


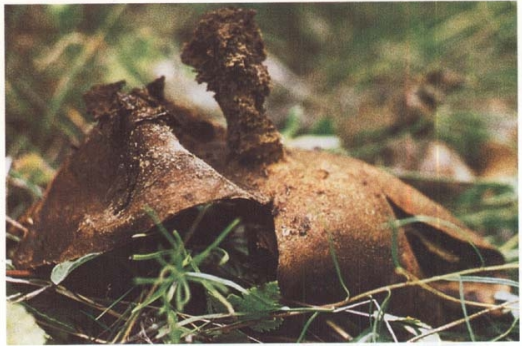

Fig. 3. Geasirum melanocephahm in the forest community resembling the dry form of the Violo adorarae-Ulmetum association in the Bielinek Reserve on the Odra river (Phot. A. Bujakiewiez)

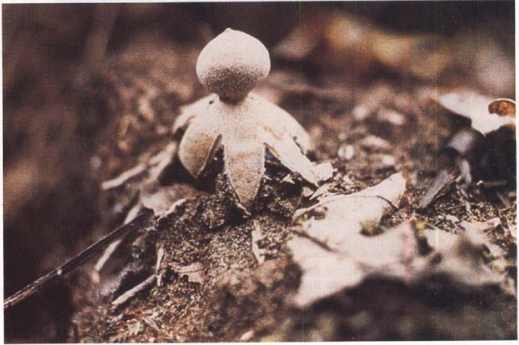

Fig 4. Geastrum minimum in the xerothermophilous sward Linosyridi-Stipetum in the Bielinek Reserve on the Odra river (Phot. A. Bujakiewicz) 
Oudemansiella radicata (Relh.) Sing., Mycena inclinata ( $\mathrm{Fr}$.) Quél. and Phallus impudicus L.: Pers. On burnt soil, in litter and among mosses Antracobia macrocystis (Cke.) Boud. was noted.

In a similar forest, on beech logs $\mathrm{C} \mathrm{e} \mathrm{l} \mathrm{i} \mathrm{ńs} \mathrm{k} \mathrm{i} \mathrm{and} \mathrm{F} \mathrm{il} \mathrm{i} \mathrm{pe} \mathrm{k} \mathrm{(1958a)}$ recorded Oudemansiella mucida (Schrad.: Fr.) v. Hoehn and Craterellus cornucopioides L. in litter. They also noted Geastrum fimbriatum Fr. Later $\mathrm{S} \mathrm{k}$ i r g i e $1+$ o (1984) mentioned Inocybe patouillardii Bres. Neither of those species was recorded by the author again.

Sporadic records of macrofungi were also made in phytocoenoses of the peculiar Lithospermo-Quercetum association whose only locality in Poland is the one found in the studied area. They are as follows. Ascomycota: Diatrype disciformis (Hoff.: Fr.) Fr. (det. A. Chlebicki), Otidea onotica (Pers.) Fuck. Basidiomycota: Amanita phalloides (Vaill.: $\mathrm{Fr}$.) Secr., Boletus impolitus $\mathrm{Fr}_{\mathrm{r}}$, B. luridus Fr., Bovista aestivalis (Bonord.), Demoulin, Byssomerulius corium (Fr.) Parm., Calocybe gambosa (Fr.) Donk, Calvatia excipuliformis (Schaeff.: Pers.) Perd., Clavulina cinerea (Fr.) Schroet., Collybia butyracea (Bull.: Fr.) Quél., C. dryophilla (Bull.: Fr.) Kummer, C. peronata (Bolt.: Fr.) Sing., Crinipellis stipitarius (Fr.) Pat., Geastrum rufescens Pers. (det. K. Křiž), Geastrum melanocephalum (Czern.) Stanek, Hygrophorus eburneus (Bull.: Fr.) Fr., Inocybe asterospora Quél., I. dulcamara (Alb. et Schw.: Pers.) Kummer, Lactarius piperatus (L.) F. Gray, L. quietus Fr., Marasmius bulliardii Quél., M. oreades (Bolt.: Fr.) S. F. Gray, Mycena polygramma (Bull.: Fr.) S.F. Gray, M. pura (Pers.: Fr.) Kummer, $M$. sanguinolenta (Alb. et Schw.: Fr.) Kummer, M. zephirus (Fr.: Fr.) Kummer, Polyporus arcularius (Batsch) ex Fr., P. brumalis (Pers.) ex Fr., Russula cyanoxantha Schaeff:: Fr., R. foetens $\mathrm{Fr}$., Scleroderma verrucosum (Bull.) ex Pers. (det. K. Křiž), Suillus granulatus (L.: Fr.) O. Kuntze, Trametes hirsuta (Wulf: Fr.) Pil. and Xerocomus subtomentosus (L.: Fr.) Quél.

Geastrum melanocephalum (Fig. 3), a fungus of continental (pontic) distributional type was recorded in Bielinek by $\mathrm{C} \mathrm{e} \mathrm{l} \mathrm{i} \mathrm{n} \mathrm{s} \mathrm{k} \mathrm{i} \mathrm{and} \mathrm{F} \mathrm{il} \mathrm{i} \mathrm{pe} \mathrm{k}$ (1958a, b) and all their collections (June 12.1954, July 17.1955, Oct. 10. 1955) are kept in the POZM. Fruit-bodies observed by the author on 6. July, 1976 and 10. September, 1981 were growing at the same locality as indicated in the former records: near Bielinek settlement, on the south-western slope, above the claypit (Fig. 1) in the xerothermic forest and scrub with Ulmus campestris, Prunus spinosa, Quercus sessilis and Lithospermum purpureo-coeruleum, in the forest community resembling Violo-Ulmetum (B u j a k i e w i c z 1989). The present distribution of this species in Poland is given by $\mathrm{L} \mathrm{is} \mathrm{i} \mathrm{e} \mathrm{w} \mathrm{s} \mathrm{k} \mathrm{a}$ (1997).

K r e is e 1 (1987) recorded Amanita caesarea in Bielinek without specifying the habitat. It is a fungus ecotomycorrhizal with the oak (Quercus) 
and with chestnut (Castanea) growing in southern Europe. Due to the thermophilous character of the forests in the Bielinek Reserve the occurrence of this species is highly probable. However, during the studies in the years 1974-1976 it was not recorded.

Several records of macrofungi were made also in phytocoenoses resembling the Linosyridi-Stipetum pulcherrimae, namely: Crinipellis stipitaria ( $\mathrm{Fr}$.) Pat., Gastrosporium simplex Matt. (rev. K. Kř̌iž), Geastrum minimum Schwein. (det. K. Křiž) and Mycena epipterygia (Scop.: Fr.) S.F. Gray.

Gastrosporium simplex was recorded for the first time in Poland from Bielinek Reserve by $\breve{\mathrm{S}} \mathrm{m}$ a r d a (1957). Specimens collected by the author on 31 May 1975 and 24 May 1976 were growing in the soil among the roots of Stipa capillata, together with Anthericum liliago, Salvia pratensis, Orobanche sp. and Fissidens cristatus. The fungus is probably a parasite (K r e is e 1 1987).

Geastrum minimum grew among Hieracium pilosella, Calamintha vulgaris, Vincetoxicum officinale, Anthoxanthum odoratum and Fissidens cristatus on 27. November 1974 and 21. September 1976 (Fig. 4).

Both Gastrosporium simplex and Geastrum minimum are constant elements of xerothermophilous swards. In the recent years these fungi were noted in the phytocoenoses of Sisymbrio-Stipetum capillatae in the vicinity of Busko Zdrój ( $\measuredangle$ u s z c z y ń s k i and $\measuredangle$ u s z c z y ń s k a 1991-1992). Geastrum minimum occurs with much higher frequency, for instance in Festucetum pallentis in the Ojców National Park (W o j e w o d a 1975).

Friedrich (1991) points out that the search for Gastrosporium simplex undertaken by him repeatedly both in the Bielinek Reserve and within Cedynia Landscape Park were not successful. Even in the past as close as the years 1975 and 1976 fruit-bodies of Gastrosporium simplex were found frequently during the studies carried out at that time. Overgrowing of swards with scrubs and trees in the Bielinek Reserve may be a factor responsible for the less frequent occurrence of this fungus. It represents the group of endangered species (W o je w o d a and $k$ a w r y n o w i c z 1992).

$\mathrm{D}$ ö $\mathrm{r}$ f e $1 \mathrm{t}$ (1974) described a fungi alliance accompanying swards in Halle and Magdeburg District and named it Tulostomato (brumali) -Gastrosporietum (simplicis) Dörfelt (Dörfelt 1977). The distribution range of this group of fungi extends probably further to the east.

Crinipellis stripitaria shows a larger distribution range. It grows on roots and grass remnants, both in xerothermous swards (W o j e w o d a 1979;

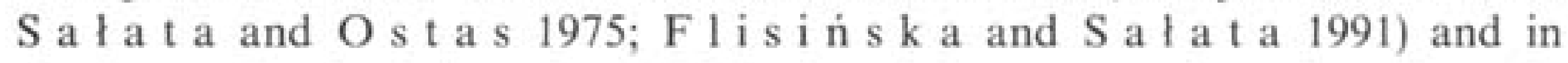
the forest ( $\mathrm{B} \mathrm{u} \mathrm{j} \mathrm{a} \mathrm{k} \mathrm{i} \mathrm{e} \mathrm{w} \mathrm{i} \mathrm{c} \mathrm{z} \mathrm{1995),} \mathrm{though} \mathrm{it} \mathrm{seems} \mathrm{to} \mathrm{have} \mathrm{been} \mathrm{brought}$ there. The occurrence of this species in ruderal communities and on the roadsides was noted by $\mathrm{K} r$ e is e 1 (1987). 
The site of a rare thermophilous species Montagnea arenaria (DC.) Zeller in the steppe reserve in Bielinek given by $\mathrm{Sk}$ i r g i e $\$$ o (1976) and R u d n i c k a-J e z i e r s k a (1991) deserves also our attention. The occurrence of this species was not noted again.

Steppe swards in the Bielinek Reserve deserve a separate mycological study.

\section{RESULTS AND REMARKS}

- In the course of mycological studies carried out in the Bielinek Reserve on the Odra river in the years 1974-1976 the total number of 149 macromycete species was noted.

- Mycocoenological studies carried out in phytocoenoses of the Violo odoratae-Ulmetum association showed the occurrence of fruit-bodies of 121 species, from which only $22(17 \%)$ occurred on both permanent study areas. The numbers indicate the differentiation of the niches inhabited by fungi with simultaneous uniformity of habitats in the slope alluvial forest. The analysis of ecological groups of fungi shows the prevalence of lignicolous and litter saprotrophs ( $84 \%$ ) (Table 2). The composition of macromycetes in the Violo odoratae-Ulmetum alluvial forest is close to Ficario-Ulmetum campestris which supports the hypothesis of the floristic and ecological affinity of these forest associations. The phytocoenoses of the Violo odoratae-Ulmetum in the Bielinek Reserve are exceptional due to a group of species indicating a nitrophilousthermophilous character of this forest community. These species are: Bovista aestivalis, Conocybe ambigua, C. mesospora, C. subovalis, Lepiota castanea, L. cristata, Macrolepiota procera and Marasmius scorodonius.

- Among the species noted in the Lithospermo-Quercetum phytocoenoses there were Boletus impolitus, B. luridus and Geastrum rufescens. The species noted in the Potentillo-Stipetum swards include Gastrosporium simplex and Geastrum minimum. These are mostly calciphilous fungi.

- Some species rarely found in Poland, such as: Gastrosporium simplex, Geastrum melanocephalum (Fig. 3), Hydropus subalpinus, Peniophora limitata, Xerocomus rubellus and Clitopilus hobsonii were noted.

- Some of the recorded species are endangered in the whole territory of Poland (W o j e w o d a and $\mathbf{L}$ a w r y n ow i c z 1992). These are: Boletus impolitus, Dacrymyces capitatus, Gastrosporium simplex, Geastrum melanocephalum and G. rufescens, and - from the group of less endangered species Conocybe ambigua, Geastrum minimum, Hehenbuehelia reniformis, Lepiota setulosa, Macrolepiota procera, Peniophora limitata and Pluteus pseudorobertiii.

- The alluvial elm forest, Violo odoratae-Ulmetum represents a fertile, nitrophilous-thermophilous wing of alluvial forests. These habitats require further more thorough mycocoenological studies based on phytocoenoses well described with regard to their geneses. 


\section{REFERENCES}

Arnolds E. Th. W. Kuyper, M. E. Noordeloos (eds.) 1995. Overzicht van de Paddestoelen in Nederland. Nederlandse Mycologische Vereinigung. CIP-Gegevens Koninklijke Bibliotheek, Den Haag.

B r ze g A. 1989. Roslinnoșé pólnocnej czesci międzyrzecza Prosny, Czarnej Strugi i Warty. Zaklad Ekologii Roślin i Ochrony Środowiska UAM, Poznan (mse).

B u j a k i c w i c z A. 1973. Udzial grzybów wyższych w lasach lęgowych i olesach Wielkopolski. PTPN Prace Kom. Biol. 25 (6): 1-91.

$\mathrm{Bujak}$ iew icz A. 1989. Macrofungi in the alder and alluvial forests in various parts of Europe and North America. Opera Botanica 100: $29-41$.

$\mathrm{B} u \mathrm{ja} \mathrm{k}$ i e w i c z A. 1992. Macrofungi on soil in deciduous forests. Handbook of Vegetation Science 19. In: W. Winterhoff (ed.) Fungi in Vegetation Science: 49-78. Kluwer Acad. Publ.

$\mathrm{B}$ u j a $\mathrm{k}$ i cw i cz A. 1995. Fungi. Agaricales. In: General problems and taxanomic groups analysis, In: J. B. F a I i is $\mathrm{k}$ i and W. M u $1 \mathrm{e} \mathrm{n} \mathrm{k}$ o (eds.). Cryptogamous plants in the forest communities of Bialowicza National Park (Project CRYPTO) Phytocoenosis, 7 (N.S.) Archiwum Geobot. 4: 141-148.

C eli ṅs k i F. 1969. Objaśnienia do mapy roślinnosci Wielkopolskiego Parku Narodowego w skali 1: 10 000, mse. Dyrekcja Wielkopolskiego Parku Narodowego.

$\mathrm{Celi}$ ins $\mathrm{ki} F, \mathrm{Filipe} \mathrm{k} \mathrm{M}$. 1958a. Flora i zespoly rostlinne lestno-stepowego rezerwatu w Bielinku nad Odra. PTPN Bad. Fizjogr. nad Polską Zach. 4: 1=198.

Celinsk i F. Filipek. M. 1958b. Nowe stanowisko Trichaster melanocephahus Crern. w Biclinku nad Odra. PTPN Bad. Fizjogr, nad Polska Zach. 4: 231-238.

De n n is R. W. G. 1978. British Asconycetes. J. Cramer, Vaduz.

Dörfelt H. 1974. Mykofloristische, mykocoenologische und mykogeographische Studien in Naturschutzgebieten mit Xerothermstandorten in Süden der DDR. Diss. Martin-LutherUniversität Halle (mse).

D o rfe 1 t H. 1977. Besonderheiten der Pilzflora des Naturschutzgebietes Oehsenburg-Naturschutz und naturkundliche Heimatforschung in den Bezirken Halle und Magdeburg. Naturschutz. 14,1: 70-79.

Enderle M., Kriegels t e in er G. J. 1989. Die Gattung Lepiota (Pers.) S. F. Gray em. Pat. in der Bundesrepublik Deutschland (Mitteleuropa). Zeitsch. f. Pilzk. 55 (1): 43-104.

Fili pe k M. 1974. Murawy kserotermiczne regionu Dolnej Odry i Warty. Prace Kom. Biol. PTPN 38. Poznani-Warszawa.

Flis ins k a $Z_{3}, S$ a l a a B. 1991. Materialy do poznania fory grzybów wielkoowocnikowych (macromycetes) kilku regionów poludniowo-wschodniej Polski. Ann. UMCS, SecC 46 (2): 13-19.

F r i ed rich S. 1991. Rzadkie i zagrożone grzyby wielkoowocnikowe w projektowanym Cedyriskim Parku Krajobrazowym. Zesz. Nauk. AR w Szczecinie 149, Rolnictwo 60: 107-I 19.

G u m i ń s k a B. 1994. Mikoflora Pieniniskiego Parku Narodowego. VI. Fragm. Flor. Geobot. Ser. Polonica 1: 33-39.

H a nsen L. K n udsen H. 1992. Nordic Macromycetes. Vol, 2. Polyporales, Boletales, Agaricales, Rus,sulales. Nordsvamp. Copenhagen, $474 \mathrm{pp}$.

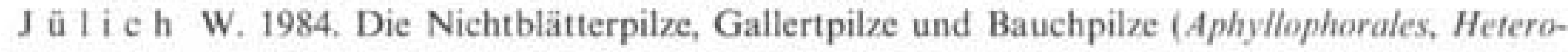
basidiomycetes, Gastromyceles). Kleine Kryptogamenflora. II b/1 Stuttgart.

$\mathrm{J}$ a h n H.. $\mathrm{N}$ espiak $A_{4}$. $\mathrm{T}$ ü $\mathrm{x}$ n $\mathrm{R}$. 1967. Pilzsoziologische Untersuchungen in Buchenwäldern des Wesergebirges. Mitt. Flor-50z. Arbeitsgem. N. F. 11/12; 159-197.

$\mathrm{K}$ o f $\mathrm{f} \mathrm{R}$. P., W e $\mathrm{n}-\mathrm{y}$ i $\mathrm{n} \mathrm{g} \mathrm{Z}$ h u a $\mathrm{n} \mathrm{g}$ 1991. A preliminary discomycete flora of Macoronesia: Part 15. Terfeziaceae and Orideaceae. Orideoideae. Mycotaxon 40: 413-433.

Kreise 1 H. 1987. Pilzlora der Deutschen Demokratischen Republik. Basidiomycetes. VEB G. Fischer. Verl-, Jena. 
L is i ew s k a M. 1997. A new locality of Geastrum melanocephalum (Crern.) Stanek in the vicinity of Poznan. Acta Mycol. 32 (2): 2: 227-230.

$\ell u s z c z y n s k$ i J, $\ell$ uszcz y ńsk a B. 1991(1992). Nowe stanowiska Gasteromycetes w okolicy Buska Zdroju. Acta Mycol. 27 (2): 221-223.

M a t usz k i c w i c z J. M. 1993. Krajobrazy roślinne i regiony geobotaniczne Polski. Instytut Geografii i Przestrzennego Zagospodarowania PAN, Prace Geograficzne 158. Wroclaw, Warszawa, Kraków.

M o s e r M. 1983. Keys to Agarics and Boleti. Publ. Roger Phillips. London.

Nespiak A. 1990. Flora Polska. Grzyby (Mycota) 19: Basidiomycetes, Agaricales, Cortinariaceae, Inocybe. PWN, Warszawa-Kraków.

$\mathrm{P}$ i o t r o w s k a H. 1983 (1985). Violo odoratae-Ulmefum z Wolina na tle tęgów wiązowych Polski. Fragm. Flor. Geobot. 29 (1): 39-51.

R e id D. A. 1974. A monograph of the British Dacrymycetales. Tran. Br. mycol. Soc. 62 (3): 433-494.

R u d n i cka-J e z i e rs k a W. 1991 (1992). Flora Polska. Grzyby (Mycota) 23: Basidiomycetes, Lycoperdales, Sclerodermatales, Tulostomatales, Nidulariales, Phallales, Podaxales, $\mathrm{PWN}$, Kraków,

$\mathrm{S}$ a I a $\mathrm{t}$ a $\mathrm{B}_{4}$, Ostas T. 1975. Nowe stanowiska interesujących grzybów wyżsych (macromycetes) w poludniowo-wschodnicj Polsce. Fragm. Flor. Geobot. 21, 4: 521-526.

S k i r g i e llo A. 1970. Materialy do poznania rozmieszczenia geograficznego grzybów wyEszych w Europic. III. Acta Mycol. 6 (1): 101-123.

S k i r g i e 11 o A. 1976 (1977). Materialy do poznania rozmieszczenia geografiçnego grzybów wyzszych w Europie. V. Acta Mycol. 12 (2): 155-189.

Skirgiello A. 1984. Materialy do poznania rozmieszczenia geograficznego grzybów wyższych w Europie. VI. Acta Mycol. 20 (1): 129-157.

S̆ m a r d a J. 1957. Prispevek k poznani Gasteromycetü v Polsce. Acta Soc. Bot. Pol. 26 (2): 317-324.

$\mathrm{S} u$ s i ck a M. 1994. Udzial grzybów (macromycetes) w fitocenozach lęgu Violo odratae-Ulmetum (Weevers 1940) H. Doing 1962 i lęgu wiązowego Ficario-Ulmetum campestris Knapp 1942 w rez. Puszczykowskie Góry w Wielkopolskim Parku Narodowym. Zakł. Ekol. Roślin i Ochr. Srod., UAM, Poznañ (msc.).

Wa tling R. 1974. Macrofungi in the oak woods of Britain. The British Oak: 222-234.

W a $t$ ing R. 1982. Bolbitaceae: Agrocybe, Bolbitis and Conocybe. British Fungus Flora. Agarics and Boleti 3. Edinburgh.

W a $t$ i i g g R. 1995. Assessment of fungal diversity: macromycetes, the problems, Can. J. Bot. 73. (Suppl. 1): 515-524.

W o je w o da W. 1974. Macromycetes Ojcowskiego Parku Narodowego. I. Flora. Acta Mycol. $10(2): 181-265$.

Woje wo da W. 1975. Macromycetes Ojcowskicgo Paku Norodowego. II. Charakterystyka socjologiczno-ekologiczno-geograficzna. Acta Mycol. 11 (2): 163-209.

Wojewoda W. 1977. Flora Polska. Grzyby (Mycota) 8: Basidiomycetes, Tremellales, Auriculariales, Septobasidiales. PWN, Warszawa-Kraków.

W oj e w o d a W. 1979. Rozmieszczenie geograficzne grzybów tremelloidalnych w Polsce. Acta Mycol. 15 (1): $75-144$.

Woje wo da $W_{4}, \mathrm{~L}$ a w r y n ow i c z M. 1992. Red list of threatened macrofungi in Poland. In: K. Zarzycki, W. Wojewoda and Z. Heinrich (eds.) List of threatened plants in Poland (2. ed.) PAN, Kraków: 27-56.

W os A. 1994. Klimat niziny Wielkopolskiej. Wydaw. Nauk. UAM Poznañ, pp. 192.

W os A. 1996. Zarys klimatu Polski. Wydaw. Nauk. UAM. Poznań, pp. 301. 


\title{
Macromycetes fitocenoz zespołu Violo odoratae-Ulmetum w rezerwacie w Bielinku nad Odrą
}

\author{
Streszezenie
}

Studia mikocenologiczne przeprowadzono w latach 1974-1976 na dwóch stalych powierzchniach w legu Violo odoratae-Ulmetum (Weevers 1940) H. Doing 1962. Sklad macromycetes tego lęgu zbliżony jest do lęgu wiązowego Ficario-Ulmetum campestris. Wyróżnia go grupa grzybów wskazujaca na nitrofilno-termofilny charakter siedliska, a mianowicie: Bovista aestivalis, Conocybe ambigua, C. mesospora, C. subovalts, Lepiota castanea, L. cristala, Marasmius scorodonius, Macrolepiota procera.

Sporadyczne obserwacje poczyniono równieź w lasach Lithospermo-Quercetum oraz w murawach Linosyridt-Stipetum pulcherrimae. Potwierdzono występowanie na tym terenie rzadko notowanych w Polsce gatunków kserotermofilnych wapieniolubnych, np. Boletus impolitus i Gastrosporium simplex. Odnotowano również znane z tego terenu stanowisko Geastrum melanocephalum. 